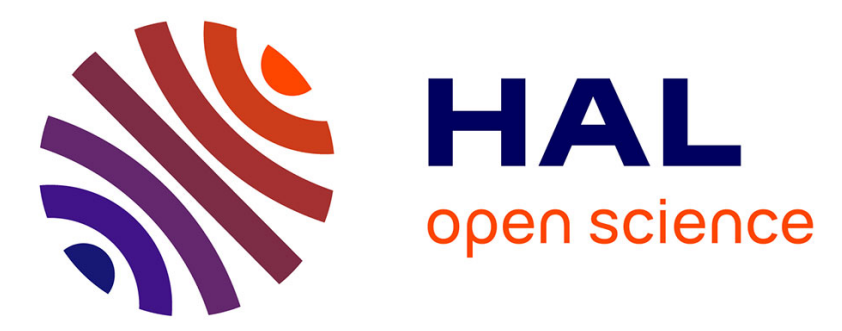

\title{
Chemical interaction between Quercus pubescens and its companion species is not emphasized under drought stress
}

H. Hashoum, J. Gavinet, T. Gauquelin, Virginie Baldy, Sylvie Dupouyet, Catherine Fernandez, Anne Bousquet-Mélou

\section{To cite this version:}

H. Hashoum, J. Gavinet, T. Gauquelin, Virginie Baldy, Sylvie Dupouyet, et al.. Chemical interaction between Quercus pubescens and its companion species is not emphasized under drought stress. European Journal of Forest Research, 2021, 140, pp.333-343. 10.1007/s10342-020-01337-w . hal-03032888

\section{HAL Id: hal-03032888 \\ https://hal.science/hal-03032888}

Submitted on 1 Dec 2020

HAL is a multi-disciplinary open access archive for the deposit and dissemination of scientific research documents, whether they are published or not. The documents may come from teaching and research institutions in France or abroad, or from public or private research centers.
L'archive ouverte pluridisciplinaire HAL, est destinée au dépôt et à la diffusion de documents scientifiques de niveau recherche, publiés ou non, émanant des établissements d'enseignement et de recherche français ou étrangers, des laboratoires publics ou privés. 
Hashoum H. ${ }^{1}$, Gavinet J. ${ }^{1}$, Gauquelin T. ${ }^{1}$, Baldy V. ${ }^{1}$, Dupouyet S. ${ }^{1}$, Fernandez C. ${ }^{1 x}$, Bousquet-Mélou A. ${ }^{1 x, *}$

\title{
Chemical interaction between Quercus pubescens and its companion species is not emphasized under
}

\section{drought stress}

${ }^{1}$ Institut Méditerranéen de Biodiversité et d’Écologie marine et continentale (IMBE) - Aix Marseille Univ, Avignon Université, CNRS, IRD, IMBE, Marseille, France

${ }^{\mathrm{x}}$ Equal contribution as last authors

* corresponding author: anne.bousquet-melou@imbe.fr

\begin{abstract}
How plant-plant interactions will interact with global change drivers such as increased drought during the regeneration phase is a key question to forecast future vegetation dynamics. Chemical interaction and especially allelopathy and drought have been suggested to affect plant performance synergistically, i.e. that plant under drought stress would be more sensitive to allelochemicals and that exposure to allelopathic interactions could increase drought sensitivity through an inhibition of root development and mycorrhization. In this paper, we tested these hypotheses by using a controlled experiment with Quercus pubescens Mill. as a target species and three cooccurring species plus itself as source species. Allelopathic treatments consisted of annual provision of litter and monthly watering with green leaf aqueous extracts during 2 vegetation seasons starting from oak acorns. During the second vegetation season, a drought stress treatment was added on half of the seedlings. Allelopathy of cooccurring species reduced seedlings dimensions while $Q$. pubescens treatment increased it. During the second vegetation season, seedling growth rate and physiology were reduced by drought but poorly affected by allelopathic treatment. At the end of the experiment, drought stress and allelopathy from Cotinus coggygria and Pinus halepensis both reduced seedling biomass but had opposite effects on the root/shoot ratio. Drought and allelopathy did not interact significantly and, contrary to our hypothesis, there was a tendency of lower allelopathic effects under drought. Our results suggest that drought and allelopathy could additively alter seedling development, but the opposite effects of allelopathy and drought on the root/shoot ratio call for further experiments testing the interaction between these two factors.
\end{abstract}

\section{Keywords}


Mediterranean oak; chemical interactions; regeneration; water stress; plant-plant interactions

\section{Declarations}

Funding: This study was funded by the French National Research Agency (ANR) through the SecPriMe2 project (ANR-12-BSV7-0016-01). The Oak Observatory at the “'Observatoire de Haute Provence’” $\left(\mathrm{O}_{3} \mathrm{HP}\right)$ site is supported by the French National Research Infrastructure ANAEE-F

Availability of data and material: the data will be available upon request to the corresponding author 


\section{Introduction}

Plant regeneration plays a central role in the dynamics of plant populations and communities, particularly early phases including germination, growth and establishment of seedlings (Nathan and Muller-Landau 2000; Nathan and Ne'eman 2004; Grubb 1977). These demographic stages are influenced by both biotic and abiotic factors (Lortie et al. 2004). In Mediterranean forests, summer drought is among the most constraining factors for seedling establishment, which often represent an important bottleneck for species regeneration (e.g. Marañón et al. 2004; Pérez-Ramos et al. 2012). Furthermore, summer drought stress is expected to increase with climate change consequently to globally rising temperatures and changing precipitation patterns (IPCC 2014, Giorgi and Lionello 2008) which may reinforce the drought limitation for seedling establishment (Pérez-Ramos et al. 2013).

Biotic factors such as plant-plant interactions are also particularly important for plant regeneration. The surrounding vegetation can influence seedling establishment processes by a change of resource availability and microclimate (Gómez-Aparicio et al. 2005; Prévosto et al. 2016; Gavinet et al. 2016a), but also through chemical interactions (Fernandez et al. 2009; Gavinet et al. 2019; Weir et al. 2004). Plant-plant chemical interactions, i.e. allelopathy (Rice 1984), can be positive - typically through nutrient release - or negative due to the release of phytotoxic compounds. Negative chemical interactions play an important role in Mediterranean ecosystems (Vilà and Sardans 1999) and in particular in forest succession dynamics (Alías et al. 2006; Fernandez et al. 2008, 2013, 2016). For example, specialized compounds produced by plants (terpenoids and/or phenolic compounds) can delay seed germination, inhibit seedling growth (Mallik 2003) or affect root symbionts (Einhellig 1999; Mallik and Zhu 1995) which play a key role during summer drought by improving seedling water and nutrient uptake (Sardans and Peñuelas 2013). Specialized compounds can also indirectly affect seedling development through modified nutrient cycles during the litter decomposition process (Chomel et al. 2014; Kuiters 1990; Kainulainen et al. 2003; Gavinet et al. 2019). Phenolic compounds are mostly soluble and can be released from plant leaves during rainy events or during the litter decomposition process. Terpenoids in contrast are highly volatile and may interact with surrounding plants in their gaseous phase after volatilization, either from living leaves or from litter (Santonja et al. 2019). Allelopathic potential has long been examined through isolation of compounds and laboratory tests on model species such as Lactuca sativa, with the aim of identifying potential natural herbicides. However, the investigation of allelopathic interactions in natural ecosystems, especially forests, require more realistic experiments, testing the effects of natural extracts of plant materials on co-occurring species, taking into account the phenological stages of the interacting species (Inderjit \& Weston 2000).

The interaction between drought and plant-plant interactions has been intensively debated (Maestre et al. 2005, 2009; Michalet 2007) and this debate becomes particularly important when trying to forecast global change impact 
on plant distribution (Michalet and Pugnaire 2016). The interaction between drought and shading has been intensively studied (e.g. Sánchez-Gómez et al. 2006; Holmgren et al. 2012; Laanisto and Niinemets 2015) but drought and chemical interactions have rarely been studied jointly. Drought could impact plant-plant chemical interactions by increasing the production of allelochemicals by source plants (Einhellig 1999; Pedrol et al. 2006; Gatti et al. 2014) or fostering the production of compounds with greater phytotoxic activities (Oueslati et al. 2005; Gatti et al. 2014). Plants may be more sensitive to allelochemicals under drought stress (Pedrol et al. 2006) and allelopathy may aggravate drought stress by antagonistic effects on root development: allelopathy is often inhibiting root development (e.g. Gavinet et al. 2019), while increased biomass allocation to roots is a well-known morphological response to drought aiming at increasing seedling ability to capture belowground water (Dickson and Tomlinson 1996; Lloret et al. 1999; Poorter et al. 2012).

Quercus pubescens Willd. (downy oak) forests represent more than one million hectares in France. Downy oak often occurs in the transition of several climatic influences and is sensitive to drought at the seedling stage (Morin et al. 2010), which translates into frequent regeneration failure in the Mediterranean (Prévosto et al. 2013; Gavinet et al. 2016b). The natural regeneration from seeds of Mediterranean oaks is uncertain, as many obstacles can hinder the process: poor seed supply, lack of an effective dispersal vector, high predation on seeds or difficulties in setting up seedlings (Puerta-Piñero 2010; Pausas et al. 2009). Emergence, survival and growth of oak seedlings are highly variable depending on the microsite (Prévosto et al. 2011; Pérez-Ramos et al. 2013). This variability is often related to competition for resources with existing vegetation, but allelopathic interactions may also contribute to the definition of oaks regeneration niche ( $\mathrm{Li}$ and Romane 1997; Gavinet et al. 2019). Downy oak acorns are likely to be dispersed in places surrounded by species with important contents of phenolics or terpenoids and known to exhibit allelopathic potential such as Pinus halepensis (Fernandez et al. 2008), Acer monspessulanum L. or Cotinus coggygria Scop. and Q. pubescens itself. Indeed, in Mediterranean forest, A. monspessulanum is a companion species of downy oak in the tree stratum while the shrub C. coggygria can dominate the understorey in supramediterranean conditions (Hashoum et al. 2017). P. halepensis also coexists with Downy oak in warmer and drier environments (Santonja et al. 2015a). The chemical content of the four source species has been analyzed in several previous studies. Aqueous extracts from needles, roots and litter of $P$. halepensis contain large amounts of compounds belonging to different functional phytochemical groups likely to induce allelopathic effects (monoterpenes, sesquiterpenes, phenolics; Fernandez et al. 2009; Gavinet et al. 2018). Allelochemicals from $P$. halepensis are known to slow down the germination of herbaceous species (Fernandez et al. 2006; Fernandez et al. 2013; Santonja et al. 2019) or the growth of tree species such as Q. pubescens especially in early stage of its development (Fernandez et al. 2016) but also the growth of $P$. halepensis via autotoxicity (Fernandez et al. 2008). 
Aqueous extracts from green leaves, senescent leaves and litter of A. monspessulanum, C. coggygria and Q. pubescens contain flavonoids such as quercetin, isorhamnetin and naringenin, compounds with reported allelopathic activities (Paszkowski and Kremer 1988; Macias 1995). Notably, allelopathic effects from those aqueous extracts have been reported on the germination and growth of two herbaceous target species occurring in the same community (Linum perenne and Festuca ovina) with senescent leaves extract that inhibited seeds' germination velocity while green leaves extract impacted seedlings growth (Hashoum et al. 2017). Moreover, total phenolics, terpenes and nutrients contents of the litter are also described in Gavinet et al. 2018 and Santonja et al. 2015a.

In this study, we performed a greenhouse experiment to test how Q. pubescens seedlings establishment is affected by plant-plant chemical interactions with itself and three co-occurring species (A. monspessulanum, C. coggygria. and $P$. halepensis), and how these chemical interactions interact with drought. We hypothesized that i) chemical interactions alter oak seedlings development by decreasing root biomass and mycorrhization, ii) exposure to chemical interactions consequently increase seedlings sensitivity to drought and iii) oak seedlings under drought stress are more sensitive to allelochemicals.

\section{Material and Methods}

\subsection{Plant and soil material}

Plants and soils used in this experiment were collected at the Oak Observatory $\left(\mathrm{O}_{3} \mathrm{HP}\right)$ at the "'Observatoire de Haute Provence’’ (Hashoum et al. 2017), in a supramediterranean forest site. Acorns of Q. pubescens from different trees were collected in autumn 2014 and visually sorted to eliminate those damaged, infested or aborted and to select acorns of roughly similar size. The selected acorns were layered in a moist substrate consisting of sand and organic substrate (50:50) at $4^{\circ} \mathrm{C}$ until the radicle appeared. Litter from the four source species used $(Q$. pubescens, A. monspessulanum, C. coggygria and P. halepensis) was collected in autumn 2014 directly after the fall of the senescent leaves using tarpaulins placed under the trees, separated according to the different species in order to obtain pure litters from each species, and stored in the laboratory in the dark at ambient temperature. Green leaves of the four source species were harvested each month of the growing season (April to October) during all the experiment duration.

The soil used for the experiment was collected in January 2015 and used directly to prepare the substrate for plantations. 


\subsection{Experimental design}

The experiment took place at the botanical garden of Mediterranean Institute of Biodiversity and Ecology, AixMarseille University, Marseille, South of France. The climate is typically Mediterranean with a mean annual temperature of $14.9^{\circ} \mathrm{C}$ and mean annual precipitations of $536 \mathrm{~mm}$ (1921 - 2019), mainly distributed in spring and autumn with a dry summer season. Two hundred acorns were sowed in February 2015 in 6L pots (1 acorn per pot, $18.3 \mathrm{~cm}$ wide, $25.5 \mathrm{~cm}$ high) filled with a substrate composed of 50\% natural soil, $25 \%$ peat moss substrate, and 25\% perlite. The use of natural soil ensures that soil microorganisms naturally present in $Q$. pubescens forests of the $\mathrm{O}_{3} \mathrm{HP}$ site were in the pot.

In order to relate as closely as possible to natural conditions, we considered two of the main release modes of allelochemicals into the environment (Rice 1984): litter decomposition and leachates, i.e. leaching of water-soluble compounds from leaves during rain events. Allelopathic treatments are thus the addition of litter of source species (litter decomposition mode) and aqueous leaf extracts of source species (leachates). The use of aqueous extracts is justified because it is widely recognized that water-soluble compounds are those most often involved in allelopathy (Vyvyan 2002). Allelopathic treatments were applied from February 2015 to April 2016 on 40 pots per source species + a control ( 5 treatments applied on 40 pots each). For each source species, the pot was supplied with $25 \mathrm{~g}$ of litter in February 2015 and 15g in October 2015 in order to simulate the annual leaf fall, and watered with leaf extracts every month. Depending on the phenological stage of the plant on the $\mathrm{O}_{3} \mathrm{HP}$, leaves used for extract preparation were green leaves (vegetation season), senescent leaves (autumn) or litter (winter). The two processes of chemical interactions through leachates and litter have thus been investigated jointly here to mimick natural conditions. The control was supplied with fiberglass cloth used to imitate the physical litter effect but without releasing allelochemicals (Sydes and Grime 1981; Gavinet et al. 2018) and watered with water. To determine the quantity of leaf litter supply, we measured the natural leaf litter amount of each species on the forest site in ten $400 \mathrm{~cm}^{2}$ blocks, then a common average value of $25 \mathrm{~g}$ per pot was used for all source species. A net was placed on each pot to prevent litter loss or addition. Aqueous extracts were prepared with fresh foliar material macerated in water for 24 hours at ambient temperature. To determine aqueous extracts concentrations on a leaf dry mass basis, a sample of fresh green leaves were dried and weighed to determine the leaf water content of each species.

During the first year (from February 2015 to April 2016), $500 \mathrm{ml}$ of aqueous extracts at 2.5\% (weight/volume) were added to each pot of the allelopathic treatment every month. The second year (from April 2016 to October 2016), half of the pots of each treatment were submitted to a water stress treatment by reducing water supply to maintain the pots at $20 \%$ of field capacity, while the other half were maintained at field capacity (not stressed). Soil moisture was maintained through an automatic drip irrigation system. Water-stressed pots submitted to allelopathic treatments were supplied monthly with $125 \mathrm{ml}$ of aqueous extracts at $10 \%$, aiming at keeping the same 
amount of compounds but less diluted than the allelopathic pots under no-stress treatment. Our design thus mimick a first year with no drought stress followed by a second year with drought stress, keeping the allelopathic treatment constant (Figure 1). Treatments of chemical interactions are referred hereafter by the Genus name of the source species, i.e. Acer, Cotinus, Quercus and Pinus.

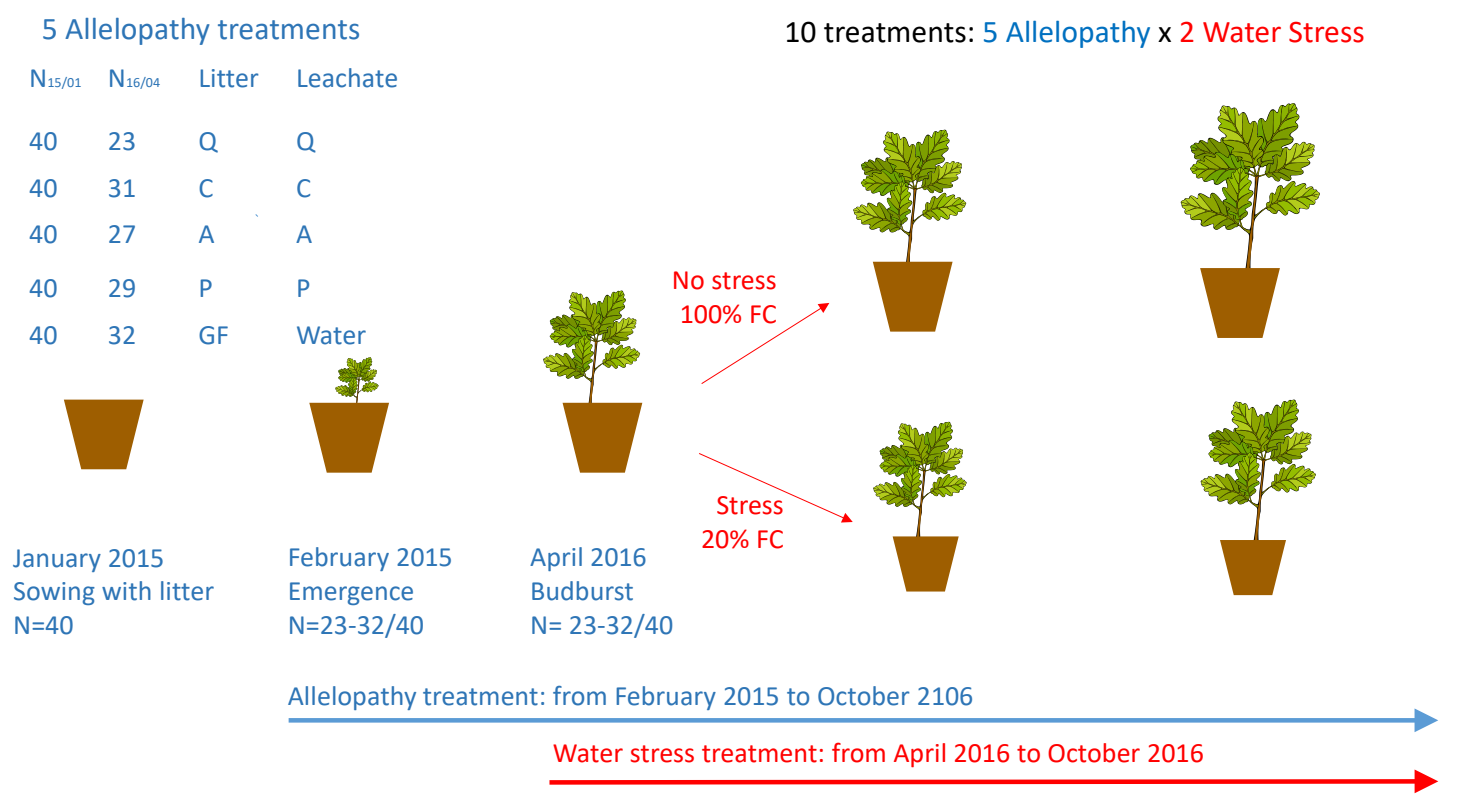

Fig1: Schematic drawing of the experimental design used to test biotic interactions between companion species and Q. pubescens under drought. The biotic interactions applied through the decomposition of litter and the supply of aqueous extract are designated by the initial of the genus name $(\mathrm{Q}$ : Q. pubescens; C: C. coggygria; A: A. monspessulanum; P: P. halepensis; GF: glass fiber; FC: field capacity; $\mathrm{N}_{15 / 01}, \mathrm{~N}_{16 / 04}$ : number of replicates followed by the corresponding date). In April 2016, each treatment was then divided in two subsamples, one submitted to water stress and the other kept at field capacity.

\subsection{Plant growth response}

Seedling size (height and diameter at ground level) was measured at the end of the first growing season, in November 2015, and at the end of the second growing season, in October 2016. At the end of the second growing season, seedlings were harvested, and root systems were gently washed above a sieve to remove soil particles without losing roots. Seedlings were separated between leaves, stems, coarse and fine roots (diameter $<2 \mathrm{~mm}$ ), oven-dried at $60^{\circ} \mathrm{C}$ for 4 days and weighed. The total number of leaves was also recorded for each seedling. 


\subsection{Plant physiological response, mycorrhization rate and litter decomposition}

$\mathrm{CO}_{2}$ and $\mathrm{H}_{2} \mathrm{O}$ exchanges were measured four months after the application of water stress, in August 2016, on a subsample of 10 seedlings per treatment and on one leaf per seedling. Each leaf was clipped in a PLC3 Universal Cuvette (diameter $18 \mathrm{~mm}, 2.5 \mathrm{~cm}^{2}$ surface) relied to an Infrared Analyzer (Synersy, CIRAS 3 PPSystem). Gasexchange measurements allowed direct calculations of net photosynthesis $\left(A, \mu \mathrm{mol} \mathrm{CO}_{2} \mathrm{~m}^{-2} \mathrm{~s}^{-1}\right)$, stomatal conductance to water vapor $\left(g s, m m o l . m^{-2} . s^{-1}\right)$ and transpiration $\left(E, \mu m o l ~ \mathrm{H}_{2} \mathrm{O} \mathrm{m} \mathrm{m}^{-2} \mathrm{~s}^{-1}\right)$. Measurements were

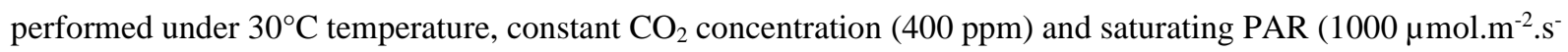

${ }^{1}$ ). Five measurements were recorded (one measurement every ten seconds), and the average of the five recordings was used for statistical analysis.

In this experiment, we also evaluated the percentage of ectomycorrhizal colonization. This type of symbiotic association is largely represented in Mediterranean forest species where fungi develop mainly around the root, forming a mycelian mantle from which hyphae develop (Duponnois et al., 2013). More, they can modify the sensitivity of plants to allelopathic substances. (Gallet and Pellissier, 2002). We took root samples from each modality directly after the seedlings were collected, at the end of the experiment. Then these samples were stored in $60 \%$ alcohol until the time of analysis. We randomly selected 5 samples per modality for analysis, for a total of 50 samples. To quantify the percentage of ectomycorrhizal colonization, we used the line intersection method (Giovannetti and Mosse, 1980). This semi-quantitative method is based on the control of mycorrhization at all points of intersection between the roots present and a grid $(1 \mathrm{x} 1 \mathrm{~cm})$ placed under a Petri dish. 5 fragments of $3 \mathrm{~cm}$ of roots are therefore analyzed in a Petri dish with a few milliliters of distilled water to prevent drying the roots. The counting is done under a binocular magnifying glass at a $4 \times 40$ magnification with high illumination to ensure good visualization. The mycorrhization rate is obtained as the ration of the number of mycorrhized root intersection points to the total number of root intersection points.

The litter from each pot was collected at the end of the experiment, freeze-dried and weighed to calculate the decomposition rate as follows: (total mass supplied - final mass) / total mass supplied.

\subsection{Statistical analyses}

Allelopathic effects on oak seedling emergence were tested using a generalized linear model with a binomial distribution. Allelopathic effects on early oak growth (length and diameter after 10 months of allelopathic treatments, before drought treatment application) were tested through 1-way ANOVA followed by Tukey posthoc tests. Seedling length and diameter relative growth rate during the second year was computed as RGR = $\left(\log \left(\mathrm{X}_{2}\right)-\log \left(\mathrm{X}_{1}\right)\right) /\left(\mathrm{t}_{2}-\mathrm{t}_{1}\right)$, with $\mathrm{X}_{2}$ is seedling dimension (height or diameter) at the last measurement date $\mathrm{t}_{2}$ 
(i.e. November 2015), and $X_{1}$ the same dimension at the first measurement date $t_{1}$ (i.e. in October 2016). Given that growth during the winter season is negligible, this value essentially represents the growth rate during the second season, when water stress was applied on half of the seedlings. The effects of allelopathy, drought treatment and their interactions on oak RGR, physiology, biomass, biomass allocation and mycorrhization rates were tested through two-ways ANOVAs. Litter mass loss was calculated as the difference of final litter mass and all litter inputs and expressed in percentage. Conditions of normality and homoscedasticity were checked using the Kolmogorov-Smirnov and Levene tests, respectively, and the data was log-transformed if necessary (seedling length, diameter and RGR).

\section{Results}

\subsection{Allelopathic effects on oak seedlings emergence and early growth}

Oak seedling emergence was only marginally influenced by allelopathic treatment $(\chi 2=7.3, P=0.06)$, with a tendency of higher emergence in control conditions than in the Quercus treatment (Figure 2). Allelopathic treatment influenced seedling length $(\mathrm{F}=18.9, P<0.001)$ and diameter $(\mathrm{F}=3.6, P=0.009)$. Seedlings had a smaller diameter in the Acer, Cotinus and Pinus treatments and a higher length in the Quercus treatment (Figure 2).
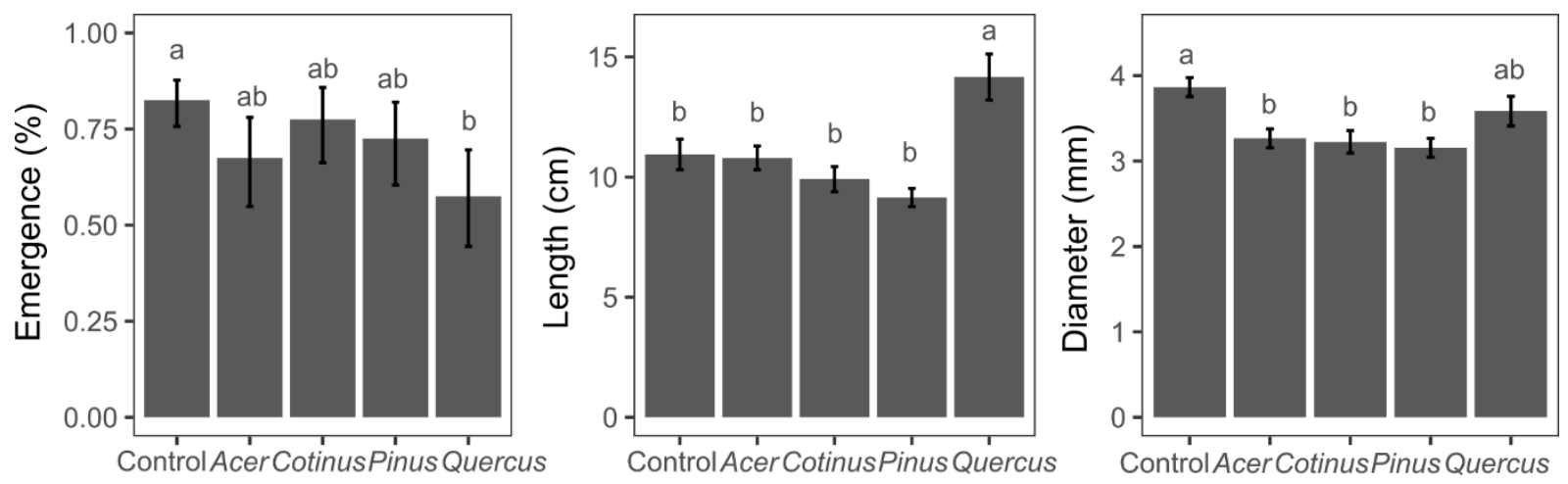

Fig2: Allelopathic treatment effects on Q. pubescens acorn emergence and early seedling growth after the first vegetation season. Different letters represent significant differences $(P<0.05$, Tukey post-hoc tests). Data are model predictions of emergence probability and means of growth variables \pm standard errors ( $\mathrm{n}=40$ acorns per treatment for emergence, $n=27-32$ acorns per treatment for growth).

\subsection{Allelopathy and drought effects on Q. pubescens growth and biomass allocation}

Seedling RGR during the second growing season was affected by drought for both height and diameter growth $(P$ $<0.001$ ) but not by allelopathy nor by the interaction between these factors (Figure 3), although allelopathy marginally influenced diameter RGR ( $P=0.07$; Figure 3) with a tendency of better growth under Pinus treatment. 


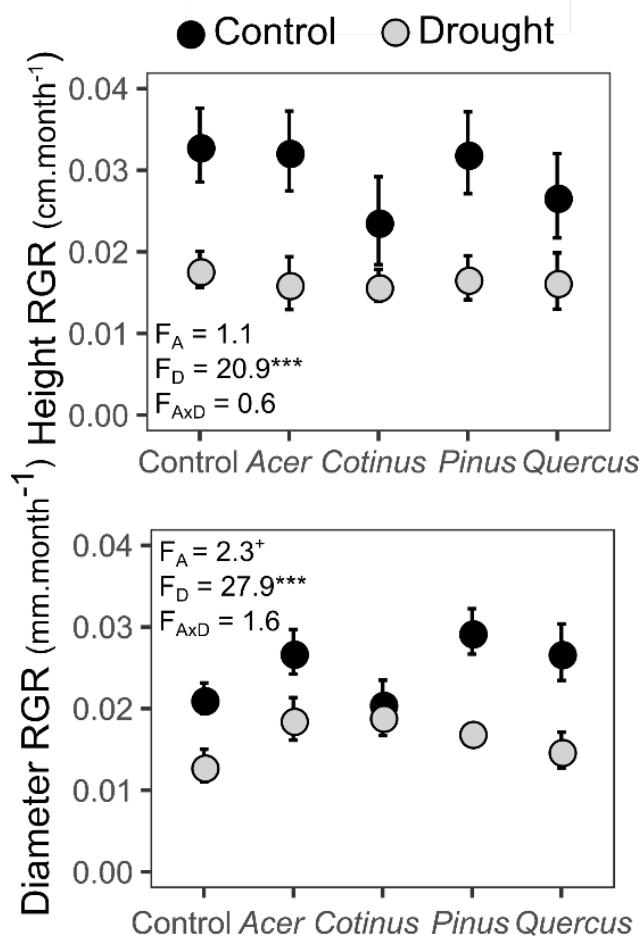

Fig 3: Allelopathy and drought effects on seedling relative growth rate (RGR) in length and diameter during the second growing season. Data are means \pm standard errors $(n=11-17$ seedlings per treatment). Results of two-ways ANOVA testing the effect of allelopathy $\left(F_{A}, D F=4\right)$, drought $\left(F_{D}, D F=1\right)$ and their interaction $\left(F_{A} \times F_{D}, D F=4\right)$ are indicated (with the symbols + for $\mathrm{P}<0.1$, * for $P<0.05$, ** for $P<0.01$ and *** for $P<0.001$ ).

Drought and allelopathy affected all biomass and biomass allocation parameters, except fine roots biomass (Figure 4). No significant interaction was detected. Over the total duration of the experiment, the drought treatment caused an average decrease of $27 \%$ of total biomass, $39 \%$ of aerial biomass, and $20 \%$ of root biomass compared to seedlings under non-stressed conditions. Drought also caused a 48\% decrease in the number of leaves, which is the most significant morphological effect of this treatment (data not shown). Litter and leachates of Cotinus led to a decrease in the number of leaves, coarse and fine root biomass, total seedling biomass and root/shoot ratio compared to the control. Root biomass and root/shoot ratio were also reduced by the Pinus treatment (Figure 4). 

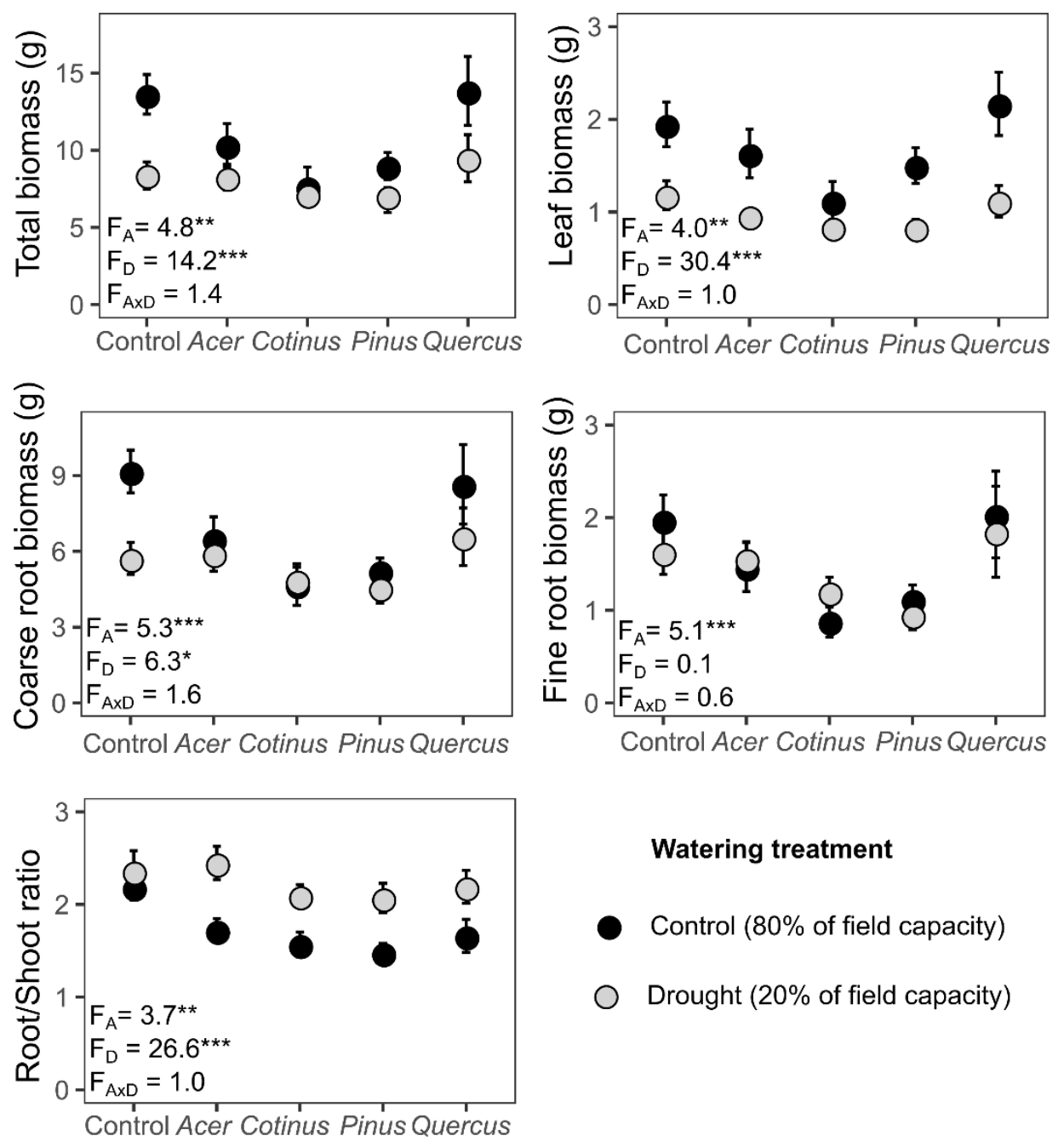

Fig 4: Drought and allelopathy effects on seedling biomass and root/shoot ratio. Allelopathy has been applied during 2 growing seasons and drought during the last growing season. Data are means \pm standard errors $(\mathrm{n}=11-17$ seedlings per treatment). Results of two-ways ANOVA testing the effect of allelopathy $\left(F_{A}, D F=4\right)$, drought $\left(F_{D}\right.$, $\mathrm{DF}=1)$ and their interaction $\left(\mathrm{F}_{\mathrm{A}} \times \mathrm{F}_{\mathrm{D}}, \mathrm{DF}=4\right)$ are indicated (with the symbols * for $P<0.05$, ** for $P<0.01$ and *** for $P<0.001)$.

\subsection{Allelopathy and drought effects on Q. pubescens physiology and mycorrhization rate}

Drought reduced stomatal conductance $\left(\mathrm{g}_{\mathrm{s}}\right)$ and photosynthesis (A) by 33.5 and $28.5 \%$ respectively compared to the unstressed condition (Figure 5). Allelopathy marginally influenced stomatal conductance $(P=0.05)$ and influenced seedling photosynthetic rate $(P=0.02)$, with in both cases seedlings under Quercus treatment having higher values than the control (Figure 5). Mycorrhization rates of Q. pubescens seedlings were generally high, ranging from about $70 \%$ to $75 \%$, with no significant differences of mycorrhization rates between drought treatments $(P=0.92)$, allelopathy treatments $(P=0.96)$ or their interaction $(P=0.84)$ (data not shown). 

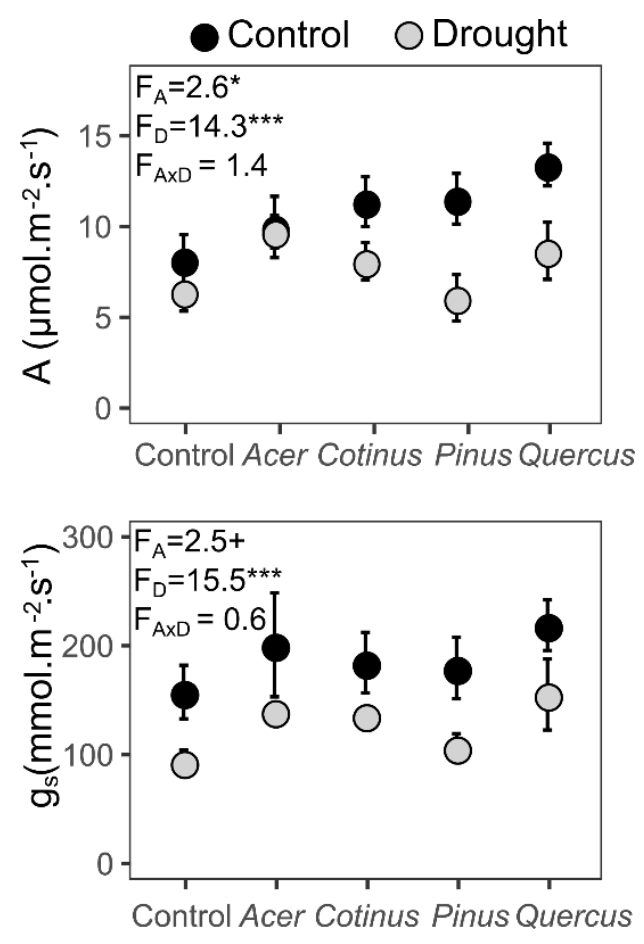

Fig 5: Allelopathy and drought effects on seedling leaf photosynthetic rate (A) and stomatal conductance ( $\left.\mathrm{g}_{\mathrm{s}}\right)$ during the summer of the second growing season. Data are means \pm standard errors ( $n=10$ seedlings per treatment). Results of two-ways ANOVA testing the effect of allelopathy $\left(\mathrm{F}_{\mathrm{A}}, \mathrm{DF}=4\right)$, drought $\left(\mathrm{F}_{\mathrm{D}}, \mathrm{DF}=1\right)$ and their interaction $\left(\mathrm{F}_{\mathrm{A}} \times \mathrm{F}_{\mathrm{D}}, \mathrm{DF}=4\right)$ are indicated (with the symbols + for $P<0.1$, * for $P<0.05$, ** for $P<0.01$ and $* * *$ for $P<0.001)$.

\subsection{Allelopathy and drought effects on litter decomposition}

Drought and allelopathy had an interactive effect on litter decomposition $\left(\mathrm{F}_{\mathrm{AxD}}=3.5, P=0.01\right.$; Figure 6$)$. Under well-watered conditions there was a difference in species decomposition rates according to the gradient Quercus $<$ Acer $<=$ Pinus $<$ Cotinus, with the Cotinus litter decomposing particularly fast with a loss of $61 \%$ of its mass at the end of the experiment under control conditions. The drought treatment reduced only the decomposition of Cotinus and Pinus litter, leading to a decrease of the difference between species in the drought treatment (Figure 6).

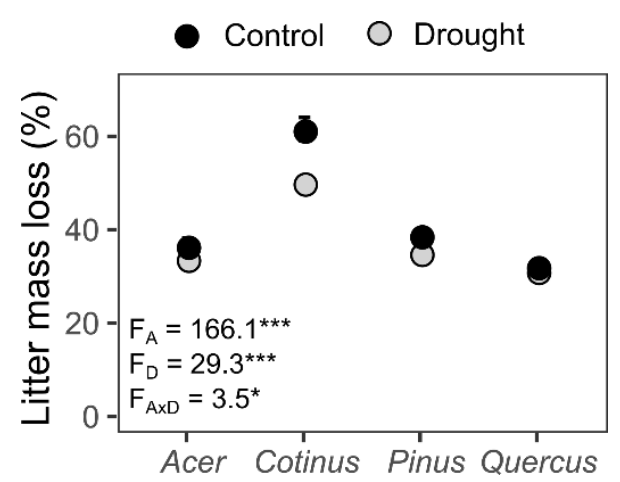


Fig 6: Litter mass loss in the different allelopathic and drought treatments. Data are means \pm standard errors ( $\mathrm{n}=11$ 17 pots of surviving seedlings per treatment). Results of two-ways ANOVA testing the effect of allelopathic source species $\left(F_{A}, D F=3\right)$, drought $\left(F_{D}, D F=1\right)$ and their interaction $\left(F_{A} \times F_{D}, D F=3\right)$ are indicated (with the symbols

* for $P<0.05$, ** for $P<0.01$ and *** for $P<0.001)$.

\section{Dis c u s s ion}

4.1 Allelopathy from companion species but not autotoxicity affects Q. pubescens seedlings development

The present results confirm the allelopathic potential of $C$. coggygria and P. halepensis, as they decreased seedling biomass and in particular root biomass of $Q$. pubescens. Several studies have found that the root part of a target plant is more sensitive to allelochemicals than the aerial part (Ben-Hammouda et al. 2001; Turk and Tawaha 2003; Gatti et al. 2010; Zhang et al. 2010). This sensitivity could be related to the root uptake role implying a direct contact between roots and allelochemicals in the soil (Turk and Tawaha 2003). Inhibition of root growth by allelochemicals may be due to changes in DNA synthesis in cells of root apical meristem, alteration of mitochondrial metabolism (Abrahim et al. 2000) or changes in cellular mitotic indices (Dayan et al. 1999; Romagni et al. 2000). As in this study, an inhibition of root development by C. coggygria leaf aqueous extracts has also been demonstrated on Q. pubescens 2-month-old seedling (Gavinet et al. 2019). However, Gavinet et al. (2018) found no effect of $C$. coggygria and P. halepensis litter on $Q$. pubescens seedlings development, which suggest that aqueous extracts may have a greater allelopathic effect than litter. The chemical composition and the quantity of allelochemicals in the leaves are highly variable between green leaves and litter leaves (Fernandez et al. 2009; Hashoum et al. 2017; Silva et al. 2014). Nektarios et al. (2005) also found that green needle extracts of $P$. halepensis had a more pronounced negative effects on herbaceous species growth than litter extracts. The supply of aqueous extracts and litter could also have cumulative effects as the concentration of available allelochemicals in soil water is a direct determinant of the phytotoxic activity of allelochemicals in soil (Kobayashi 2004). Litter decomposition allow to release nutrients and allelochemicals according to initial leaf litter quality (Chomel et al. 2014, 2016, Santona et al. 2015 a, b), and Cotinus and Pinus litter have a high concentration of phenolics and terpenoids, respectively (Santonja et al. 2015a; Gavinet et al. 2018).

We found no evidence of autotoxicity for Q. pubescens. The treatment with litter and aqueous extracts from $Q$. pubescens tended to inhibit seedling emergence but increased seedling length. These effects may be due to mechanical litter effects (Facelli and Pickett 1991; Kostel-Hughes et al. 2005). Q. pubescens litter had the largest and thickest leaves, which may constitute a greater physical barrier in line with its tendency to decrease seedling 
emergence compared to the artificial litter treatment. Xiong et al (2001) also showed that the negative effects of litter increased with the size of the litter leaves. Similarly, after cutting oak litter leaves, Li and Ma (2003) observed an increase in seedling emergence. The increase in seedling length is consistent with our hypothesis of a physical effect of Quercus litter through light interception (Facelli and Pickett 1991), which can accelerate the elongation of the stem. Interestingly, Quercus treatment improved seedling photosynthesis and transpiration. As this species litter present the lowest decomposition rate (Figure 5) and is known to release few nutrients (Santonja et al. 2015b), the positive effects of its own litter may come from improved seedling water status thanks to a lower soil moisture evaporation, as also suggested by Gavinet et al. (2018).

\subsection{Drought affect Q. pubescens seedlings physiology and growth but do not interact with allelopathy}

Water stress induced a progressive decrease in stomatal conductance and photosynthesis, a classic physiological response to drought already documented for different oak species (Chaves et al. 2002; Vaz et al. 2010, Arend et al. 2013). The reduced photosynthesis combined with a lower leaf biomass indicates a lower carbon gain for the plant, which participate to explain the lower seedling biomass under drought stress. Seedling biomass reduction by drought was particularly marked for leaves but not for roots, indicating a change in biomass allocation and an increased root/shoot ratio as expected (Poorter et al. 2012). However, contrary to our hypothesis, drought effects were not more important for seedlings submitted to allelopathic treatments. This is particularly surprising as regards the Cotinus and Pinus treatments which strongly reduced root development. These allelopathic treatments, however, caused no change in leaf carbon and water exchange rates, contrary to previous results showing that allelopathy can reduce plant water uptake, stomatal conductance or photosynthesis (Barkosky et al. 2000; Zhou and Yu 2006). In our study, seedling length and diameter relative growth during the second year did not differ between allelopathic treatments, whatever the drought stress. This suggest that i) allelopathic effects were restricted to the first phase of our experiment, ii) root biomass reduction that occurred in the first year was not strong enough to induce a reduction of water absorption by roots during subsequent drought. An element of explanation of this latter effect could be that Cotinus and Pinus treatments did not affect rooting depth, which is the main factor controlling seedling water absorption (Padilla and Pugnaire 2007). Finally, the absence of treatment effect on mycorrhization rate may hide differences in mycorrhization type : for instance, mycorrhizae with longer extrametrical mycelia may help seedlings to sustain their carbon and water exchange and growth rates (García de Jalón et al. 2020) despite lower root biomass.

Our results do not support the hypothesis of Pedrol et al. (2006) that sensitivity to allelochemicals is increased under drought stress. At the contrary, allelopathic effects tended to be less pronounced (although not significantly) under drought stress. A reduced allelopathic effect under drought stress is possible if the lower water availability 
prevents the transport of soluble allelochemicals to the roots. The dry treatment also reduced litter decomposition rate for Cotinus and Pinus, possibly limiting the release of litters' allelochemicals through volatilization or solubilization. However, it must be highlighted that drought was applied during the second year of oak seedling development only, a period during which allelopathic effects were reduced as indicated by growth and physiological measurements. Similarly, Gavinet et al. (2019) showed that Cotinus inhibited root development of young seedling but not that of older saplings. Differences of root biomass measured at the end of the experiment may thus reflect only legacy effects of the first year allelopathic effects. Drought applied during the first year, or on more sensitive target species, may lead to different results. For instance, Hashoum et al. (2019) showed that drought and allelopathy from Cotinus interact to decrease the germination of the herbaceous Linum perenne L. In addition, under natural conditions drought can be more pronounced that the drought treatment applied here and reach lethal levels for seedlings, particularly under the expected climate change (Giorgi and Lionello 2008). In that case, an inhibition of oak seedling root development by neighboring allelopathic species such as Cotinus and Pinus could reduce survival probability in case of more pronounced water stress. Finally, we have not investigated whether drought could induce changes in the production of allelochemicals by the source species, which must be considered to assess if allelopathic interactions will change under increased drought stress. However, other studies contradict this view, evidencing at the contrary a lower total phenolics production under water stress (e.g. Karageorgou et al. 2002), meaning that this issue is far from being resolved.

\subsection{Consequences for oak regeneration in different forest microsites}

In a previous study, Hashoum et al. (2017) showed that the dominant tree Q. pubescens and its companion species A. monspessulanum and C. coggygria may limit the growth of understory herbaceous plants in downy oak forests through the production and release of allelochemicals. Here, we evidenced no negative effects of Q. pubescens and A. monspessulanum on Q. pubescens seedlings, suggesting that herb inhibition by allelochemicals could be an advantage for oak regeneration since herbs are usually strong competitors for seedling establishment (Gordon et al. 1989; Coll et al. 2003; Rey Benayas et al. 2005; Gavinet et al. 2016b). In contrast, C. coggygria affects both herb and oak seedlings, pointing to a possible negative effect of this species on understory diversity and oak regeneration (Gavinet et al. 2019). Finally, P. halepensis had negative effect on oak regeneration, but strong autotoxicity have also been evidenced. Oak regeneration is often successful in pine habitats (Lookingbill and Zavala 2000), especially under moderate pine cover (Gavinet et al. 2015), indicating that allelopathy is not a strong limitation fir oak regeneration under pine.

In conclusion, our results suggest a better potential for Quercus pubescens regeneration under its own stands, due to the positive effects of its litter and leachates, but in the absence of Cotinus coggygria in the understory. 
Allelopathy does not appear to be stronger under drought stress, but further investigations are needed in particular to elucidate the consequences of the opposite effects of allelopathy and drought on the root/shoot ratio. Finally, the allelopathic treatments tested here were rather limited, particularly during their interaction with drought in the second year. Interactions with drought may be more evident in systems where allelopathy is a stronger driver of plant performance, particularly in the case of strategies adopted by Exotic Invasive Plants Species (e.g. MedinaVillar et al. 2020)

\section{Acknowledgments}

We thank Laura Magaud for help with nursery experiment. This study was funded by the French National Research Agency (ANR) through the SecPriMe2 project (ANR-12-BSV7-0016-01). The $\mathrm{O}_{3} \mathrm{HP}$ site is supported by the French National Research Infrastructure ANAEE-F

\section{References}

Abrahim, D, Braguini, WL, Kelmer-Bracht, AM, Ishii-Iwamoto, EL (2000). Effects of four monoterpenes on germination, primary root growth, and mitochondrial respiration of maize. J. Chem. Ecol. 26, 611-624.

Alías JC, Sosa T, Escudero JC, Chaves N (2006) Autotoxicity against germination and seedling emergence in Cistus ladanifer L Plant Soil 282, 327-332

Arend M, Brem A, Kuster TM, Günthardt-Goerg MS, (2013) Seasonal photosynthetic responses of European oaks to drought and elevated daytime temperature Plant Biol 15, 169-176

Barkosky RR, Einhellig FA, Butler JL (2000) Caffeic acid-induced changes in plant-water relationships and photosynthesis in leafy spurge Euphorbia esula J Chem Ecol 26, 2095-2109

Ben-Hammouda M, Ghorbal H, Kremer R, Oueslati O (2001) Allelopathic effects of barley extracts on germination and seedlings growth of bread and durum wheats Agronomie 21, 65-71

Chaves MM, Pereira JS, Maroco J, Rodrigues ML, Ricardo CPP, Osório ML, Carvalho I, Faria T, Pinheiro C (2002) How Plants Cope with Water Stress in the Field? Photosynthesis and Growth Ann Bot 89, 907-916 https://doiorg/101093/aob/mcf105

Chomel M, Fernandez C, Bousquet-Mélou A, Gers C, Monnier Y, Santonja M, Gauquelin T, Gros R, Lecareux C and Baldy V (2014) Secondary metabolites of Pinus halepensis alter decomposer organisms and litter decomposition during afforestation of abandoned agricultural zones Journal of Ecology 102, 411-424 
Chomel M, Guittony-Larchevêque M, Fernandez C, Gallet C, Desrochers A, Paré D, Jackson BG, Baldy V (2016) Secondary metabolites in plant litter : a key trait for ecosystem processes Journal of Ecology 104 (6): 1527-1541

Coll L, Balandier P, Picon-Cochard C, et al (2003) Competition for water between beech seedlings and surrounding vegetation in different light and vegetation composition conditions Annals of Forest Science 60:593-600 doi: 101051/forest:2003051

Dayan FE, Watson SB, Galindo JCG, Hernandez A, Dou J, McChesney JD, Duke, SO (1999) Phytotoxicity of quassinoids: physiological responses and structural requirements Pestic Biochem Physiol 65: 15-24

Dickson RE and Tomlinson PT (1996) Oak growth, development and carbon metabolism in response to water stress, Ann. For. Sci. 53:181-196

Duponnois R, Hafidi M, Ndoye I, Ramanankierana H, Bâ AM (2013) Généralités sur la symbiose mycorhizienne : introduction, in: Duponnois, R, Hafidi, M, Ndoye, I,

Einhellig FA (1999) An integrated view of allelochemicals amid multiple stresses Princ Pract Plant Ecol Allelochem Interact CRC Press Boca Raton 479-494

Facelli JM and Pickett ST (1991) Plant litter: its dynamics and effects on plant community structure Bot Rev 57: $1-32$

Fernandez C, Lelong B, Vila B, Mévy JP, Robles C, Greff S, Dupouyet S, Bousquet-Mélou A (2006) Potential allelopathic effect of Pinus halepensis in the secondary succession: an experimental approach Chemoecology 16, 97-105 https://doiorg/101007/s00049-006-0334-z

Fernandez C, Voiriot S, Mévy JP, Vila B, Ormeño E, Dupouyet S, Bousquet-Mélou A (2008). Regeneration failure of Pinus halepensis Mill.: the role of autotoxicity and some abiotic environnemental parameters. Forest Ecology and Management. 255 (7), 2928-2936

Fernandez C, Monnier Y, Ormeño E, Baldy V, Greff S, Pasqualini V, Mévy JP, Bousquet-Mélou A (2009) Variations in allelochemical composition of leachates of different organs and maturity stages of Pinus halepensis J Chem Ecol 35, 970-979

Fernandez C, Monnier Y, Santonja M, Gallet C, Weston LA, Prévosto B, Saunier A, Baldy V, Bousquet-Mélou A (2016) The Impact of Competition and Allelopathy on the Trade-Off between Plant Defense and Growth in Two Contrasting Tree Species Front Plant Sci 7 https://doiorg/103389/fpls201600594 
Fernandez C, Santonja M, Gros R, Monnier Y, Chomel M, Baldy V, Bousquet-Mélou A (2013) Allelochemicals of Pinus halepensis as Drivers of Biodiversity in Mediterranean Open Mosaic Habitats During the Colonization Stage of Secondary Succession J Chem Ecol 39, 298-311 https://doiorg/101007/s10886-013-0239-6

Fernandez C, Voiriot S, Mévy JP, Vila B, Ormeno E, Dupouyet S, Bousquet-Mélou A (2008) Regeneration failure of Pinus halepensis Mill: the role of autotoxicity and some abiotic environmental parameters For Ecol Manag 255: 2928-2936

Gallet C. and Pellissier (2002) Interactions allelopathiques en milieu forestier. Rev. For. Fr, LIV 6 : 567-576

Gatti AB, Ferreira AG, Arduin M, Perez SC (2010) Allelopathic effects of aqueous extracts of Artistolochia esperanzae O Kuntze on development of Sesamum indicum L seedlings Acta Bot Bras 24: 454-461

Gatti AB, Takao LK, Pereira VC, Ferreira AG, Lima MIS, Gualtieri SCJ (2014) Seasonality effect on the allelopathy of cerrado species Braz J Biol Rev Brasleira Biol 74, S64-S69 https://doiorg/101590/1519-698421512 Gavinet J, Prévosto B, Bousquet-Melou A, Gros R, Quer E, Baldy V, Fernandez C (2018) Do litter-mediated plantsoil feedbacks influence Mediterranean oak regeneration? A two-year pot experiment Plant Soil 430:59-71 doi: 101007/s11104-018-3711-9

Gavinet J, Prévosto B, Fernandez C (2016a) Introducing resprouters to enhance Mediterranean forest resilience: importance of functional traits to select species according to a gradient of pine density J Appl Ecol 53:1735-1745 doi: 101111/1365-266412716

Gavinet J, Prévosto B, Fernandez C (2016b) Do shrubs facilitate oak seedling establishment in Mediterranean pine forest understory? Forest Ecology and Management 381:289-296 doi: 101016/jforeco201609045

Gavinet J, Santonja M, Baldy V, (2019) Phenolics of the understory shrub Cotinus coggygria influence Mediterranean oak forests diversity and dynamics Forest Ecology and Management 441:262-270 doi: 101016/jforeco201903049

Gavinet J, Vilagrosa A, Chirino E, et al (2015) Hardwood seedling establishment below Aleppo pine depends on thinning intensity in two Mediterranean sites Annals of Forest Science 72:999-1008 doi: 101007/s13595-0150495-4

García de Jalón L, Limousin JM, Richard F, Gessler A, Peter M, Hättenschwiler S, Milcu A (2020) Microhabitat and ectomycorrhizal effects on the establishment, growth and survival of Quercus ilex L. seedlings under drought PLoS ONE 15(6): e0229807 doi: https://doi.org/10.1371/journal.pone.0229807 
Giorgi F, Lionello P (2008) Climate change projections for the Mediterranean region. Glob Planet Change, Mediterranean climate: trends, variability and change 63, 90-104 https://doiorg/101016/jgloplacha200709005

Giovannetti M, Mosse B (1980) An evaluation of techniques for measuring vesicular arbuscular mycorrhizal infection in roots New Phytol 84, 489-500

Gómez-Aparicio L, Gómez JM, Zamora R, Boettinger JL (2005) Canopy vs soil effects of shrubs facilitating tree seedlings in Mediterranean montane ecosystems J Veg Sci 16:191-198 doi: 101111/j1654-11032005tb02355x

Gordon DR, Menke JM, Rice KJ (1989) Competition for soil water between annual plants and blue oak (Quercus douglasii) seedlings Oecologia 79, 533-541

Grubb PJ (1977) The maintenance of species-richness in plant communities: the importance of the regeneration niche Biological reviews, 52, 107-145

Hashoum H, Santonja M, Gauquelin T, Saatkamp A, Gavinet J, Greff S, Lecareux C, Fernandez C, BousquetMélou A (2017) Biotic interactions in a Mediterranean oak forest: role of allelopathy along phenological development of woody species Eur J For Res 1-12

Hashoum H, Saatkamp A, Gauquelin T, Ruffault J, Fernandez C, Bousquet-Mélou A (2019) Mediterranean woody plant specialized metabolites affect germination of Linum perenne at its dry and upper thermal limits Plant Soil https://doiorg/101007/s11104-019-04366-6

Holmgren M, Gómez-Aparicio L, Quero JL, Valladares F (2012) Non-linear effects of drought under shade: reconciling physiological and ecological models in plant communities Oecologia 169:293-305 doi: 101007/s00442-011-2196-5

Inderjit, Weston LA (2000) Are laboratory bioassays for allelopathy suitable for prediction of field responses? Journal of Chemical Ecology 26, 2111-2118.

IPCC, 2014: Climate Change 2014: Synthesis Report. Contribution of Working Groups I, II and III to the Fifth Assessment Report of the Intergovernmental Panel on Climate Change [Core Writing Team, R.K. Pachauri and L.A. Meyer (eds.)]. IPCC, Geneva, Switzerland, 151 pp.

Kainulainen P, Holopainen T, Holopainen JK (2003) Decomposition of secondary compounds from needle litter of Scots pine grown under elevated CO2 and O3 Global Change Biol 9, 295

Karageorgou P, Levizou E, Manetas Y (2002) The influence of drought, shade and availability of mineral nutrients on exudate phenolics of Dittrichia viscosa Flora 197, 285-289 
Kobayashi K (2004) Factors affecting phytotoxic activity of allelochemicals in soil Weed Biol Manag 4, 1-7 https://doiorg/101111/j1445-6664200300112x

Kostel-Hughes F, Young TP, Wehr JD (2005) Effects of leaf litter depth on the emergence and seedling growth of deciduous forest tree species in relation toseed size J Torrey Bot Soc 132, 50-61

Kuiters AT (1990) Role of phenolic substances from decomposing forest litter in plant-soil interactions Acta Bot Neerl 39, 329-348

Laanisto L, Niinemets Ü (2015) Polytolerance to abiotic stresses: how universal is the shade-drought tolerance trade-off in woody species? Global Ecology and Biogeography 24:571-580 doi: 101111/geb12288

Li JQ, Romane FJ (1997) Effects of germination inhibition on the dynamics of Quercus ilex stands J Veg Sci 8:287-294 doi: 102307/3237358

Li Q, Ma K (2003) Factors affecting establishment of Quercus liaotungensis Koidz under mature mixed oak forest overstory and in shrubland For Ecol Manag 176, 133-146 https://doiorg/101016/S0378-1127(02)00274-8

Lloret F, Casanovas C, Peñuelas J (1999) Seedling survival of Mediterranean shrubland species in relation to root: shoot ratio, seed size and water and nitrogen use Funct Ecol 13, 210-216

Lookingbill TR, Zavala MA (2000) Spatial pattern of Quercus ilex and Quercus pubescens recruitment in Pinus halepensis dominated woodlands Journal of Vegetation Science 11:607-612 doi: 102307/3246590

Lortie CJ, Brooker RW, Choler P, Kikvidze Z, Michalet R, Pugnaire FI, Callaway RM (2004) Rethinking plant community theory Oikos 107, 433-438

Macias FA (1995) Allelopathy in the search for natural herbicide models. In: Inderjit S, Dakshini KMM, Einhellig FA (eds) Allelopathy: organisms, processes, and applications. American Chemical Society, Washington, pp 310329

Maestre FT, Callaway RM, Valladares F, Lortie CJ (2009) Refining the stress-gradient hypothesis for competition and facilitation in plant communities J Ecol 97:199-205 doi: 101111/j1365-2745200801476x

Maestre FT, Valladares F, Reynolds JF (2005) Is the change of plant-plant interactions with abiotic stress predictable? A meta-analysis of field results in arid environments J Ecol 93:748-757 doi: 101111/j1365$2745200501017 \mathrm{x}$ 
Mallik AU (2003) Conifer Regeneration Problems in Boreal and Temperate Forests with Ericaceous Understory: Role of Disturbance, Seedbed Limitation, and Keytsone Species Change Crit Rev Plant Sci 22, $341-366$ https://doiorg/101080/713610860

Mallik AU, Zhu H (1995) Overcoming allelopathic growth inhibition by micorrhizal inoculation ACS Publications Marañón T, Zamora R, Villar R, Zavala MA, Quero JL, Pérez-Ramos I, Mendoza I, Castro J (2004) Regeneration of tree species and restoration under contrasted Mediterranean habitats: field and glasshouse experiments Int J Ecol Environ Sci 30, 187-196

Medina-Villar S, Uscola M, Pérez-Corona ME, Jacobs DF (2020) Environmental stress under climate change reduces plant performance, yet increases allelopathic potential of an invasive shrub Biol Invasions (2020).

Michalet R (2007) Highlighting the multiple drivers of change in interactions along stress gradients New Phytologist 173:3-6 doi: 101111/j1469-8137200601949x

Michalet R, Pugnaire FI (2016) Facilitation in communities: underlying mechanisms, community and ecosystem implications Funct Ecol 30:3-9 doi: 101111/1365-243512602

Morin X, Roy J, Sonié L, Chuine I (2010) Changes in leaf phenology of three European oak species in response to experimental climate change New Phytol 186, 900-910 https://doiorg/101111/j1469-8137201003252x

Nathan R, Muller-Landau HC (2000) Spatial patterns of seed dispersal, their determinants and consequences for recruitment Trends Ecol Evol 15, 278-285

Nathan R, Ne’eman G (2004) Spatiotemporal dynamics of recruitment in Aleppo pine (Pinus halepensis Miller) Plant Ecol 171, 123-137

Nektarios PA, Economou G, Avgoulas C (2005) Allelopathic Effects of Pinus halepensis Needles on Turfgrasses and Biosensor Plants HortScience 40, 246-250

Oueslati O, Ben-Hammouda M, Ghorbal MH, Guezzah M, Kremer RJ (2005) Barley Autotoxicity as Influenced by Varietal and Seasonal Variation J Agron Crop Sci 191, 249-254 https://doiorg/101111/j1439-037X200500156x Padilla FM, Pugnaire FI (2007) Rooting depth and soil moisture control Mediterranean woody seedling survival during drought Functional Ecology 21:489-495 doi: 101111/j1365-2435200701267x

Paszkowski WL, Kremer RJ (1988) Biological activity and tentative identification of flavonoid components in velvetleaf (Abutilon theophrasti Medik.) seed coats. J Chem Ecol 14:1573-1582. 
Pausas JG, Bladé C, Valdecantos A, Seva JP, Fuentes D, Alloza JA, Vilagrosa A, Bautista S, Cortina J, Vallejo R (2004) Pine and oaks in the restoration of Mediterranean landscapes of Spain: New perspective for an old practiceareview. Plant Ecology, 171, 209-220.

Pedrol N, Gonzalez L, Reigosa MJ (2006). Allelopathy and abiotic stress In : Allelopathy: A Physiological Process with Ecological Implications Netherlands, Springer, 171-209

Pérez-Ramos IM, Urbieta IR, Zavala MA, Marañon T (2012) Ontogenetic conflicts and rank reversals in two Mediterranean oak species: implications for coexistence J Ecol 100, 467-477

Pérez-Ramos IM, Rodríguez-Calcerrada J, Ourcival JM, Rambal S (2013) Quercus ilex recruitment in a drier world: A multi-stage demographic approach Perspect Plant Ecol 15, 106-117 https://doiorg/101016/jppees201212005

Prévosto B, Gavinet J, Monnier Y, et al (2016) Influence of neighbouring woody treatments on Mediterranean oak development in an experimental plantation: Better form but weaker growth Forest Ecology and Management 362:89-98 doi: 101016/jforeco201511046

Prévosto B, Ripert C, Ostermeyer R (2013) Éclaircir est-il suffisant pour favoriser la régénération de taillis de chêne blanc? Retour sur un dispositif expérimental installé il y a 27 ans en forêt domaniale de Lure (Alpes-deHaute-Provence) Forêt Méditerranéenne 34:3-12

Poorter H, Niklas KJ, Reich PB, Oleksyn J, Poot P, Mommer L (2012) Biomass allocation to leaves, stems and roots: meta-analyses of interspecific variation and environmental control New Phytologist 193:30-50 doi: 101111/j1469-8137201103952x

Puerta-Piñero C (2010) Intermediate spatial variations on acorn predation shapes Holm oak establishment within a Mediterranean landscape context. Plant Ecology, 210, 213-224.

Rey Benayas JM, Navarro J, Espigares T, et al (2005) Effects of artificial shading and weed mowing in reforestation of Mediterranean abandoned cropland with contrasting Quercus species Forest Ecology and Management 212:302-314 doi: 101016/jforeco200503032

Rice EL (1984) Allelopathy. Academic, USA

Romagni JG, Allen SN, Dayan FE (2000) Allelopathic effects of volatile cineoles on two weedy plant species J Chem Ecol 26, 303-313 
Sánchez-Gómez D, Valladares F, Zavala MA (2006) Performance of seedlings of Mediterranean woody species under experimental gradients of irradiance and water availability: trade-offs and evidence for niche differentiation New Phytologist 170:795-806 doi: 101111/j1469-8137200601711x

Santonja M, Baldy V Fernandez C, Ballesdent J, Gauquelin T (2015a) Potential shift in plant communities with climate change : outcome on litter decomposition and nutrient release in a mediterranean oak forest Ecosystems 18 (7): 1253-1268

Santonja M, Fernandez C, Gauquelin T, Baldy V (2015b) Climate change effects on litter decomposition: drier climate leads to a strong decrease of litter mixture interactions Plant and Soil 393,(1-2): 69-82

Santonja M, Bousquet-Mélou A, Greff S, Ormeño E, Fernandez C (2019) Allelopathic effects of volatile organic compounds released from Pinus halepensis needles and roots. Ecology and Evolution, 0: 1-13

Sardans J, Peñuelas J (2013) Plant-soil interactions in Mediterranean forest and shrublands: impacts of climatic change Plant Soil 365, 1-33 https://doiorg/101007/s11104-013-1591-6

Silva ER, Overbeck GE, Soares GLG (2014) Phytotoxicity of volatiles from fresh and dry leaves of two Asteraceae shrubs: Evaluation of seasonal effects South Afr J Bot 93, 14-18 https://doiorg/101016/jsajb201403006

Sydes C, Grime JP (1981) Effects of Tree Leaf Litter on Herbaceous Vegetation in Deciduous Woodland: II An Experimental Investigation J Ecol 69:249-262 doi: 102307/2259829

Turk, MA, Tawaha, AM (2003) Allelopathic effect of black mustard (Brassica nigra L) on germination and growth of wild oat (Avena fatua L) Crop Prot 22, 673-677

Vaz M, Pereira JS, Gazarini LC, David TS, David JS, Rodrigues A, Maroco J, Chaves MM (2010) Droughtinduced photosynthetic inhibition and autumn recovery in two Mediterranean oak species (Quercus ilex and Quercus suber) Tree Physiol 30, 946-956

Vilà M, Sardans J (1999) Plant competition in Mediterranean-type vegetation J Veg Sci 10, 281-294

Weir TL, Park SW, Vivanco JM (2004) Biochemical and physiological mechanisms mediated by allelochemicals Curr Opin Plant Biol 7, 1-8

Vyvyan JR (2002) Allelochemicals as leads for new herbicides and agrochemicals. Tetrahedron 58: 1631-1649

Xiong S, Nilsson C, Johansson ME (2001) Effects of litter accumulation on riparian vegetation: importance of particle size J Veg Sci 12, 231-236 
Zhang C, and Fu S (2010) Allelopathic effects of leaf litter and live roots exudates of Eucalyptus species on crops Allelopathy J 26, 91-100

Zhou YH and Yu JQ (2006) Allelochemicals and photosynthesis In Reigosa, Pedrol and González (eds) Allelopathy: a physiological process with ecological implications Springer, Netherlands, 127-139 